\title{
MNC Strategies and Linkage Effects in Developing Countries
}

\author{
Hansen, Michael Wendelboe; Pedersen, Torben; Petersen, Bent
}

Document Version

Final published version

Publication date:

2007

License

CC BY-NC-ND

Citation for published version (APA):

Hansen, M. W., Pedersen, T., \& Petersen, B. (2007). MNC Strategies and Linkage Effects in Developing Countries.

Link to publication in CBS Research Portal

\section{General rights}

Copyright and moral rights for the publications made accessible in the public portal are retained by the authors and/or other copyright owners and it is a condition of accessing publications that users recognise and abide by the legal requirements associated with these rights.

\section{Take down policy}

If you believe that this document breaches copyright please contact us (research.lib@cbs.dk) providing details, and we will remove access to the work immediately and investigate your claim. 
Institutforkortelse: SMG

Forfatter(e):

Copenhagen Business School HANDELSHØJSKOLEN

CBS Bibliotek

Titel: (hvis tidsskrift husk også år, vol., nr. og sidetal)

MNC Strategies and Linkage Effects in Developing Countries

Gem blanketten på din lokale pc, udfyld den elektronisk eller i hånden.

Send blanketten til Marie Wildt, CBS Bibliotek, SP3 eller mw.lib@cbs.dk - send også kopi eller original af bog/artikel til Marie Wildt.

\begin{tabular}{|l|l|}
\hline Forskning & Sæt kryds \\
\hline 1a. Artikel i peer-reviewed videnskabeligt tidsskrift & \\
\hline 1b. Reviewartikel i peer-reviewed videnskabeligt tidsskrift & \\
\hline 1c. Boganmeldelse i peer-reviewed videnskabeligt tidsskrift & \\
\hline 1d. Editorial i peer-reviewed videnskabeligt tidsskrift & \\
\hline 1e. Kommentar/debatindlæg i peer-reviewed videnskabeligt tidsskrift & \\
\hline 2. Artikel i peer-reviewed proceedings (med ISSN-nr.) & \\
\hline 3a. Artikel i videnskabeligt tidsskrift uden peer-review & \\
\hline 3b. Reviewartikel i videnskabeligt tidsskrift uden peer-review & \\
\hline 3c. Boganmeldelse i videnskabeligt tidsskrift uden peer-review & \\
\hline 3d. Editorial i videnskabeligt tidsskrift uden peer-review & \\
\hline 3e. Kommentar/debatindlæg i videnskabeligt tidsskrift uden peer-review & \\
\hline 4a. Doktorafhandling & \\
\hline 4b. Ph.d.-afhandling & \\
\hline 4c. Videnskabelig bog, monografi & \\
\hline 5. Bidrag til videnskabelig bog/antologi (ikke genoptryk) & \\
\hline 6. Konferencebidrag: Konferencebidrag, artikel i proceedings udgivet i monografiform (med \\
ISBN) & \\
\hline 7. Andre konferencebidrag: Manuskripter, posters, abstracts (udgivne/tilgængelige) & \\
\hline 8. Videnskabelig rapport eller bidrag til videnskabelig rapport & \\
\hline 9. Working paper, arbejdspapir, preprint & \\
\hline 10. Patenter (patentansøgninger) & \\
\hline 11. Andet, lyd og billedmedie, software, musik mv. & \\
\hline
\end{tabular}

\section{Markér indsatsområde:}

Innovation, entrepreneurship og lederskab

$\checkmark$ Virksomhed og politik
Oplevelsesøkonomi

Kultur- og områdestudier $\quad \square$ Udenfor område 


\title{
MNC Strategies and Linkage Effects in Developing Countries
}

\author{
Michael W. Hansen \\ Torben Pedersen \\ Bent Petersen
}

SMG WP 2/2007

March 2007 
SMG Working Paper No. 2/2007

March 2007

ISBN: 978-87-91815-01-0

Center for Strategic Management and Globalization Copenhagen Business School

Porcelænshaven 24

2000 Frederiksberg

Denmark

www.cbs.dk/smg 


\title{
MNC Strategies and Linkage Effects in Developing Countries
}

\author{
Michael W. Hansen \\ Torben Pedersen \\ Bent Petersen ${ }^{1}$
}

Copenhagen Business School

${ }^{1}$ Corresponding author. Contact details: Center for Strategic Management and Globalization , Copenhagen Business School, Porcelaenshaven 24, $1^{\text {st }}$ floor, DK-2000 Frederiksberg. Tel: +45 3815 2510, Email: bp.smg@cbs.dk 


\title{
MNC Strategies and Linkage Effects in Developing Countries
}

\begin{abstract}
The paper addresses the question of which implications MNC strategies have to FDI linkage effects in developing countries. Two contrasting MNC strategies reflecting an integration-responsiveness dichotomy are scrutinized as to their job effects on local linkage partners in developing countries. It is hypothesized that compared to investments undertaken by MNCs following strategies of global integration, investments of MNCs pursuing local responsiveness create more jobs but imply less job upgrading in developing countries. The hypotheses are tested on a sample of Danish MNCs with extensive investments in developing countries.
\end{abstract}

Key words: Multinational corporations, strategy, linkages, developing countries. 


\section{MNC Strategies and Linkage Effects in Developing Countries}

\section{Introduction}

In recent years we have witnessed a fundamental change in the way multinational corporations (MNCs) are organising their international activities. Spurred by the lessening of trade and investment barriers in emerging markets and plunging transport and communication costs, MNCs are changing strategies in order to exploit the new opportunities for division of labor on a global scale. The surge in global sourcing and global integration within the multinational corporation is widely described by IB scholars, see e.g. Zaheer \& Manrakhan (2001), Dicken (2003) and Kotabe \& Murray (2004).

What have received less attention are the local linkage effects of this surge, that is the propensity of MNCs to link up with local firms in the locations where they operate. Yet, development economics has long recognized that the key to beneficial effects from FDIs depend on whether or not foreign investors reach out to local industry through linkages such as alliances, joint ventures, license and franchise agreements, OEM contracts, etc. Through linkages, knowledge and technology may be transferred more effectively to the host country and new opportunities for local firm development will transpire (Lall, 1980; Altenburg, 2000; Görg \& Grenaway, 2002). Without linkages, foreign investors may create enclaves in the local economy (Singer, 1950), exploiting its resources and labor, leaving few lasting positive effects on the host country (Cypher \& Dietz, 2004).

Presumably, there is a link between the global strategies of MNCs and their linkage effects. Thus, MNCs with globally integrated strategies may be relatively inclined to opt for high levels of internalization as under-performing local linkage 
partners may disrupt their global value chain and potentially damage their global brand and reputation. On the other hand, firms with locally responsive strategies may be relatively more inclined to foster linkages where they operate as they will need the resources and knowledge of local firms to adapt to local conditions and as they will tend to see each investment as a separate portfolio and therefore have less concern in regard to the quality and costs of inputs.

Based on a survey of 95 Danish investments in developing countries, this paper will examine the relationship between strategies of MNCs and local linkage effects in developing countries. The paper is organised as follows: First, we account for linkage effects: what is meant by linkage effects and what empirical evidence exists (section 1). Here we draw mainly on the development economics literature's treatment of linkages. We then turn to the IB literature about MNC strategies with the intent of carving out the various strategy dimensions of local responsiveness and global integration (section 2). In section 3 we present the conceptual model of the study and develop hypotheses about relationships between the MNC strategies and local linkage effects. Section 4 accounts for the methods of the empirical study, including data compilation, sample characteristics, operationalisation of variables, and modeling techniques. In section 5 results are presented and we discuss their validity as well as theory and policy implications. Section 6 concludes.

\section{Linkage Effects}

In this study, local linkages are narrowly defined as business transactions between foreign affiliates and domestic firms that go beyond arm's length, one-off relations 
and involve longer-term relations between the parties (UNCTAD, 2001) ${ }^{2}$. Such collaborations obviously vary in terms of their scope, scale and quality. Some MNCs may foster few linkages involving few types of activities, while others may have many types of activities spread on numerous local partners. Some MNCs may foster 'shallow' local linkages, meaning low levels of resource commitment (e.g. in terms of technical assistance, management advice, and other resources) while others may foster 'deep’ local linkages, investing massively in upgrading their local linkage partners (Hansen \& Schaumburg-Müller, 2006). Some MNCs may foster asymmetrical linkages of a mainly cost economizing nature (so-called 'transactional' linkages) in which the MNCs more or less dictate the terms of the collaboration, while other MNCs may foster linkages with a high level of reciprocity and mutual exchange of resources and knowledge - so-called 'collaborative' linkages (Scott-Kennel \& Endewick 2005).

In this study local linkage effects are seen as effects on the scale and quality of local firms' production deriving from the linkage collaboration ${ }^{3}$. Indicators of the scale of linkages are for instance number of linkages fostered to local linkage partners, share of inputs procured by local linkage partners, or number of jobs created at local linkage partners as a consequence of the linkage collaboration. Indicators of the quality of linkages are for instance upgrading of product and process performance

\footnotetext{
${ }^{2}$ A broader definition of linkages includes transactions between foreign affiliates and local nonbusiness entities like universities, training centres, research and technology institutes, export promotion agencies and other official or private institutions. In this study we use the narrow definition.

${ }^{3}$ Thereby we delineate our selves from spill over effects on firms in the host country not part of the linkage collaboration, although such effects obviously can be quite significant (see e.g. Blomström \& Kokko, 1997).
} 
at local linkage partners, improvement of learning capabilities at local linkage partners, local linkage partners' movement into new functions in the value chain, or upgrading of job-skills at local linkage partners as a consequence of the linkage collaboration. In this study we will use job-creation at local linkage partners and upgrading of skills of employees at local linkage partners as indicators of linkage effects.

Several streams of literature focus on foreign-local linkages, including the literature on international strategic alliances (see e.g. Dunning, 1997; Lundan, 2002), value chains (see e.g. Porter, 1986), resource and knowledge management (see e.g. Grant et al, 2000), and network theory (see e.g. Koza \& Lewin, 1998). In these streams of literature linkages are seen as ways in which firms can reduce coordination and transaction costs and leverage internal and external resources more effectively to increase value and competitiveness. Also more systemic perspectives address the importance of inter-firm linkages, such as the cluster literature (see e.g. Schmitz \& Nadvi, 1994), the global value chain literature (see e.g. Gereffi et al, 2005), new trade economics (see e.g. Krugman, 1991), the literature on competitiveness (see e.g. Porter, 1990; Dunning, 1992; Esser et al., 1996; UNCTAD, 2000a), and the innovation system literature (see e.g. Lundvall, 1998). These streams of literature essentially argue that we are moving towards a more network-oriented type of economic organisation, where the competitiveness of firms and nations increasingly hinges on their ability to foster linkages, alliances and collaborations.

If we look specifically at linkages between MNCs and domestic firms in developing countries, we find that linkages have received some attention in recent years (for overviews, see Altenburg, 2000; de Velde, 2002; Hoskisson et al, 2000; Lall, 2002; Görg \& Grenaway, 2004; Hansen \& Schaumburg-Müller, 2006). The 
literature emphasizes the role and limitations of developing country firm strategies implying collaboration with foreign firms. The gist of this literature is that inter-firm linkages are key mechanisms through which technology, knowledge, and market access opportunities are transferred from 'Northern' to 'Southern' firms and that strong linkages ensure that foreign investors are better grounded in the local economy (Altenburg, 2000; UNCTAD, 2001; Dicken, 2003; Scott-Kennel \& Endewick, 2005). On the other hand, the literature also recognizes the limitations to linkage-based development, including the limited upgrading opportunities for developing country linkage partners in global value chains and the subsequent danger of 'lock-in' in low value added functions (Humphrey \& Schmitz, 2001; Wad, 2006; Gereffi et al, 2005). While most of the development economics literature on linkages focuses on backward linkages (i.e. linkages to suppliers - see e.g. Lall, 1980/2002 or UNCTAD, 2001) it should be noted that forward linkages (i.e. linkages to distributors, sales agents and clients) may have equally important effects on local firms in developing countries (Hansen \& Schaumburg-Müller, 2006).

\section{Strategies of MNCs}

One of the classical discussions in the international strategy literature is that of global integration versus local responsiveness (see e.g. Prahalad \& Hamel (1987), Bartlett \& Ghoshal (1989), and Yip (1992)), where MNCs are seen as poised in a conflict between forces of global integration and local responsiveness (Doz, 1980). Following this integration-responsiveness framework, the strategies of MNCs may be seen as positioned on a bi-polar continuum where MNCs that pursue global integration and local responsiveness strategies respectively, constitute the two poles.

The integration-responsiveness framework may manifest itself in various ways in terms of intended and realized strategies. A review of the integration- 
responsiveness literature revealed three prominent manifestations of global integration and local responsiveness strategies; namely FDI motives (Dunning, 1993), value chain configurations (Porter, 1986), and intra-corporate coordination between parents and affiliates (Gupta \& Govindarajan, 2000), see Figure 1.

--- Insert Figure 1 about here ---

Although other dimensions of the integration-responsiveness framework (such as managerial orientation) indeed are conceivable we will nevertheless focus on these three manifestations which, in conjunction, make up a good proxy. In the following outline of the three manifestations the bipolar (or dichotomous) approach is maintained for expository reasons. However, in the real world few - if any - MNCs will exercise strategies that unconditionally aim for either global integration or local responsiveness. Most - if not all - MNCs will combine strategies of integration and responsiveness in their pursuit of 'transnational solutions' (Bartlett \& Ghoshal 1989) or ‘network configurations’ (Forsgren 2002).

\section{FDI motives}

The investment motives of MNC are important not only for intended, but also for realized strategies. A classical account of foreign direct investment strategies is offered by John Dunning (1993) who essentially makes a distinction between market seekers and efficiency seekers. Market seekers are companies investing to service a market of a particular country or region. Market seeking investments may be undertaken either to sustain or protect an existing market, or to exploit or promote new markets. In contrast, efficiency seekers are companies investing to tap into resources and assets abroad, not only for local use (in which case the sourcing would comply with a market seeking motive), but for use by the corporation as a whole. Thus, the purpose of the investment is to obtain advantages of common ownership, of 
internal division of activities and capabilities, or advantages of implementing similar activities and capabilities in different locations (Dunning, 1993). The resources sought for may be natural resources, cheap labor or local technological capability, management or marketing experience (Dunning, 1993).

Historically, FDIs in developing countries were mainly motivated by exploitation of natural resources and abundant labor pools (Hertner \& Jones, 1986; Wilkins, 1998). The investors viewed these investments as a means to access relatively undifferentiated and cheap resources of raw materials or labor not available in the home country. As developing country economies picked up, and a growing number of countries embarked on import substitution industrialization strategies, FDI increasingly became directed toward accessing local markets. Typically, MNCs considered such market seeking FDIs as portfolio investments only playing modest roles in their global strategies. The value chain of the market seeking investor was typically dispersed (se also next paragraph), implying replication of downstream activities (marketing, sales, and customer servicing). In recent decades foreign investors in developing countries have moved towards efficiency seeking investment motives as indicated by the emergence of globally integrated production systems and networks (Evans, 1998; Cypher \& Diez, 2004). In this regard, investments in developing countries are playing greater roles in the strategies of MNCs, creating global efficiencies through economies of scale and scope and through access to complementary assets such as innovative capacity.

\section{Value chain configuration}

How the various value chain activities of an MNC are localised constitute an important manifestation of its realised strategy and structure. In the case MNCs are localising value chain activities across country borders one may speak about global 
value chain configurations (Porter, 1986). Porter (1986) distinguishes between dispersed and concentrated global value chain configurations. In the former case, a company locates its international activities in a scattered way, where value chain activities are replicated from country to country. In some countries, only a few activities, such as marketing and sales, are carried out, whereas in other countries the corporation may replicate the full range of activities of the value chain, in this way forming 'minireplica'. Figure 2 exemplifies a dispersed value chain configuration of an MNC based in the UK with minireplicas in the USA and Japan and marketing and sales outlets in multiple countries.

---Insert Figure 2 about here ---

In contrast, firms may configure their value chain in such a way that the individual activity is carried out in only one location. In the extreme case, all value chain activities of a firm are carried out in different countries, taking full advantage of factor endowment differentials. The local subsidiary is the sole supplier of specific activities in the firm's value chain and, as such, it is assigned a corporate world mandate. In other words, an international division of labor unfolds within the value chain of the corporation. Obviously, such a well-developed international division of labor renders a need for extensive coordination among the various units of the MNC. Figure 3 exemplifies a concentrated value chain configuration of an MNC with five discernable value chain activities - management, R\&D, IT, manufacturing, and logistics - concentrated in singular locations (the UK, the USA, India, China, and Ireland, respectively). In this example only the downstream activities of marketing \& sales are replicated in multiple countries.

--- Insert Figure 3 about here ---

Intra-corporate coordination 
A third and last manifestation of MNC strategies to be highlighted is the extent to which MNC affiliation activities are mutually coordinated. In this respect we are echoing Michael Porter’s configuration-coordination dichotomy from 1986. According to Porter (1986) close affiliate coordination follows a concentrated value chain configuration, whereas a dispersed configuration only renders a modest need for coordination. The varying coordination needs are reflected by the few and many interaffiliate connecting lines depicted in Figure 2 and 3, respectively. Inter-affiliate coordination manifests itself in terms of flows of goods, services, capital, and knowledge. The 'mini-replica' affiliates may operate quite independently of other MNC units (see Figure 2). In contrast, the highly specialized affiliates with worldwide, corporate mandate (Holm \& Pedersen, 2000; Frost et al, 2000) operate in a symbiotic way with other nodes in the MNC network of affiliates (Figure 3). The outgoing flows of goods, services, and knowledge are considerable, but the specialized affiliates are dependent on substantial ingoing flows as well.

In sum, we are arguing that MNCs' international strategies can be placed on a continuum between pursuit of local responsiveness or global integration. The two poles, in turn, can be translated into three dichotomous manifestations in terms of investment motives, value chain configuration, and intra-corporate coordination. In that order, the dichotomies are: market seeking vis-à-vis efficiency seeking, dispersed versus concentrated value chain configuration, and low against high inter-affiliate coordination.

\section{Conceptual Model and Hypotheses}

Linkage effects can be attributed to a variety of factors, including the development level of the host country (Dunning \& Narula, 1996; Scott-Kennel \& Endewick, 2005), the age and duration of foreign investments (Blomström \& Kokko, 1997), the 
competencies and absorptive capacity of the local firms and industries (UNCTAD, 2000b; Altenburg, 2000), corporate culture (UNCTAD, 2000b), home country of the investor (Larimo \& Tahir, 2003); entry mode of the investor (Hansen \& SchaumburgMüller, 2006); CSR and development outlook of the investor (Best, 1999); the investor's international experience (Castellani \& Zanfei, 2002) as well as the governance structure of global value chains (Humphrey \& Schmitz, 2001). Here, we focus specifically on how linkage effects are shaped by the three MNC strategy manifestations outlined above: namely FDI motives, value chain configuration, and intra-corporate coordination. We will trace these three manifestations of MNC strategy in linkage effects, making a distinction between the scale of linkages (measured in terms of number of jobs created at local linkage partners) and the quality of linkages (measured in terms of the resource commitment made by the foreign investor in upgrading the local linkage partner).

Figure 4 shows the conceptual model of the study: MNC strategies of local responsiveness are positively related to local job creation in developing countries (left-hand side of the figure), whereas strategies pursuing global integration are associated with local job qualification (right-hand side of figure).

---Insert Figure 4 about here ---

Several authors trace linkage effects back to investment motives: Thus, Reuber et al (1973), UNCTAD (2000a), Altenburg (2000), Belderbos et al (2001), and Dicken (2003) found that the propensity of foreign affiliates to forge local linkages is affected by the motive for investing in a host country. Market seekers are argued to develop many local linkages partly because demands to obtaining 
economics of scale and high quality performance is less pressing, partly because they often operate in sectors where local content requirements force them to foster linkages. Market seeking investments therefore have raised less concern from a public policy perspective, as they have been seen as highly adapted to local business environments (Wilkins, 1998). By contrast, efficiency seeking investors are believed to create relatively fewer linkages. This is because efficiency seeking investors typically will operate in export oriented industries where demands on quality and costs of inputs are much higher than those of national markets in developing countries (Dicken, 2003). Some observers tend to argue that efficiency seeking investors foster few and 'shallow' linkages,, e.g. aimed at providing low cost, simple inputs, as seen in the garment industry (Evans, 1998; Cypher \& Diez, 2004) while others tend to argue that linkages between export oriented affiliates and local firms will be few but deep and imply extensive product and process upgrading as the foreign investor must ensure that local linkage partners can meet quality and other performance requirements in integrated export markets (UNCTAD, 2000b; Hansen et al, 2006). Based on the above discussion we conjecture the following two hypotheses:

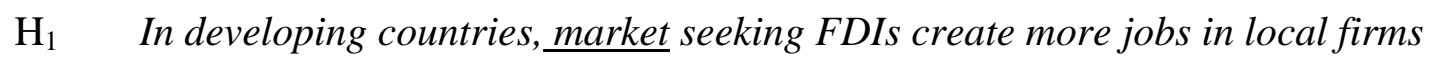
than do efficiency seeking FDIs.

$\mathrm{H}_{2} \quad$ In developing countries, efficiency seeking FDIs induce more job upgrading in local firms than do market seeking FDIs.

In terms of value chain configuration, a dispersed value chain configuration is characterized by value chains in different foreign locations that replicate the value 
chain of the MNC's home base. Since the interdependence of activities in these locations is modest, the consequences of fostering linkages to local firms that may not be able to meet global standards for quality, delivery and price are less fatal. However, as MNCs move towards increasingly integrated global value chain configurations, they will have to scrutinize and control their local linkage partners, simply because the costs of opportunism in the value chain increases dramatically with integration. In the highly integrated firm, the withdrawal of one unit may have serious consequences for the entire network (Forsgren, 2002; Forsgren et al, 2005). Thus, the expectation is that firms with concentrated value chain configurations have strong preferences for internalization of foreign activities and foster relatively few local linkages. On the other hand, it can be argued that where inputs are sourced locally, the investor will invest large resources in introducing safeguards and upgrading the local partners. In accordance with this we formulate two additional hypotheses:

$\mathrm{H}_{3} \quad$ In developing countries, investments of MNCs with dispersed value chain configurations create more jobs in local firms than do investments of MNCs with concentrated value chain configurations.

$\mathrm{H}_{4} \quad$ In developing countries, investments of MNCs with concentrated value chain configurations induce more job upgrading in local firms than do investments of MNCs with dispersed value chain configurations.

As regards intra-firm coordination, several authors have argued that the degree of affiliate autonomy affects local sourcing and linkages (see e.g. Zanfei, 2000). On 
the one hand, it is argued that low levels of intra-firm coordination lead to more intense linkages. For instance, UNCTAD (2000) speculates that TNC strategies characterized by decentralized corporate decision making and local management empowered to initiate local sourcing and local product development are conducive of deep linkages. In the same vein, Dicken (2003) argues that MNCs that are strongly vertically integrated on a global scale are less likely to develop local supply linkages than firms with a lower degree of corporate integration. On the other hand, it is conversely argued that closely coordination leads to strong linkages. Thus, affiliates considered to be 'centres of excellence', with regional or global mandates for complete products, services or technology, will tend to integrate more with local suppliers (Holm \& Pedersen, 2000; Frost et al, 2000). Similarly, Forsgren (2002) argues that loosely coordinated affiliates will produce less transfer of knowledge and technology, as the primary orientation of the activity of the affiliate is local standards, not global standards. On this background we offer a last pair of hypotheses:

$\mathrm{H}_{5} \quad$ In developing countries, loosely coordinated MNC affiliates create more jobs in local firms than do closely coordinated MNC affiliates.

$\mathrm{H}_{6} \quad$ In developing countries, closely coordinated MNC affiliates induce more job upgrading in local firms than do loosely coordinated MNC affiliates.

\section{Method}

\section{Data collection}

The six hypotheses pertaining to the relationship between international strategies of MNCs and linkage effects of their investment in developing countries are tested on a data set of Danish firms (MNCs). The data originate from a mail survey conducted by 
the authors during the period September-December 2005. A questionnaire was submitted to 131 Danish firms with ongoing equity operations in developing countries (as per year 2005) all of which had received financial or advisory services from the government-controlled Industrialization Fund for the Developing Countries (IFU). Most variables in the questionnaire were measured on interval level Likert scales (17). The 131 targeted firms represented all in all 190 affiliates in developing countries. The usable responses included 72 Danish companies covering 95 affiliates. This yields a response rate as high as $55 \%$. Further details and preliminary findings of the survey are published in Hansen et al (2006).

\section{Sample characteristics}

In the survey conducted, companies were asked about the geographical distribution of their global activities - thereby giving an indication of how exposed the companies are to international activities. One measure of international scope of the company's activities is the proportion of workers employed abroad. On average, 2,556 employees out of a total number of 3,011 employees worked outside. Hence, the Danish companies included in the sample are highly internationalized with a high proportion of their employees - $85 \%$ - working abroad. The employees working abroad are - not surprisingly - distributed unevenly in regards to developed and developing countries,

with the bulk of the workforce being employed in other developed countries. Nevertheless, slightly more than $20 \%$ were employed in developing countries. This suggests that not only are the sample firms highly internationalized: they have also substantial experience in conducting activities in developing countries. It is also worth noticing that the number of workers employed in developing countries in fact exceeds the amount of employees in Denmark, which underlines a high priority of activities in 
developing countries. In other words, developing countries play an important role for the companies included in this study.

It is evident from the survey that the profiles of employee activities in Denmark and developing countries differ considerably In particular, a much higher share of the workforce in developing countries - $45 \%$ - is employed in production (manufacturing) as opposed to only $30 \%$ in Denmark. Conversely, more sophisticated activities - such as R\&D - represent a much larger proportion of employees in Denmark: the percentage is four times higher in Denmark compared to developing countries. The share of employees dealing with logistics and purchasing, sales and marketing, as well as administration, is also somewhat higher in Denmark. All in all, this suggests a focus on low skill production activities in developing countries. Danish MNCs tend to locate production in low-cost areas, whereas activities demanding higher skills still are managed at home. Nonetheless, some $\mathrm{R} \& \mathrm{D}$, sales and marketing, and administration activities do take place in developing countries. Danish MNCs do not solely offshore to reduce production costs; instead, a variety of motives exists when Danish MNCs undertake business activities in developing countries.

\section{Operationalization of variables}

The dependent variables, i.e. the linkage effects of local job creation and qualification, were measured in the following ways:

Local job creation was measured as absolute number of jobs. The question posed to the respondents was: How many jobs has the MNC's affiliate(s) created among suppliers, distributors, and other local business partners in the host country?

Local job qualification was gauged by asking the following question: Is the company affiliate(s) providing resources to local counterparts in terms of: (1) training 
'on location'; (2) training in MNC affiliate; (3) training in Denmark; (4) assistance in management; (5) technical assistance; (6) transfer of technology; and (7) financial assistance? The variable can take the value from 0 to 7 depending on in how many of these areas the MNC affiliate provides resources to local counterparts.

The independent variables, the MNC strategies, were measured in the following ways:

FDI motives: Three items were used to create a factor-score for the investment motive. These three items were two motive variables - to what extent was the motive: (1) access to local market, and (2) access to cheap labour - and one export variable, namely the export-intensity (export/total sales) of the MNC affiliate. The three items are highly correlated and only one factor (with eigenvalue $>1$ ) emerges in the factor-analysis. This factor-score, which is used as our investment motive variable, is constructed so that higher values translate into increased importance of efficiency seeking motives and conversely less importance of the market seeking motive (and vice versa).

Value Chain Configuration: Companies were asked to indicate whether the following activities were conducted abroad in order to serve the local market or the global market: (1) research \& development; (2) logistics \& purchasing; manufacturing; (4) services; (5) sales \& marketing; and (6) administration. Based on the responses an index was created as the sum of activities conducted for the global market divided by the sum of activities conducted for the local market. This index expresses the extent to which the activities abroad are conducted for the global market, implying a concentrated value chain configuration.

Inter-affiliate Coordination: Four items were used to create a factor-score for the level of coordination. These four items were the flows among MNC units of: 
(1) goods; (2) services; (3) knowledge; and (4) financial resources. The four items are highly correlated and only one factor (with eigenvalue $>1$ ) emerges in the factor analysis. The factor score is used as our coordination variable and is constructed in such a way that higher values should be interpreted as higher levels of inter-affilate coordination.

\section{Model Estimation}

In order to test for multicolleniarity problems binary correlations were measured for all independent and dependent variables in the models.

--- Insert Table 1 about here ---

As can be seen from the correlation matrix (Table 1) none of the independent variables have correlation coefficient above 0.5, which is the usual threshold for detecting problems of multicolleniarity. Therefore, we do not expect any multicolleniarity problems. In fact, the significant correlation coefficients of 0.16 0.32 among the three independent variables indicate that the three manifestations of global integration and local responsiveness strategies are related and overlapping, but certainly not identical. Each variable is expressing different dimensions of the underlying strategy. The same holds true for the two dependent variables. With a significant correlation coefficient of 0.27 they are related, but still different dimensions.

Finally, the models were tested as two OLS-models with the dependent variables of local job creation and local job qualification, respectively

\section{Results and Discussion}

The results of the OLS regression are shown in Table 2.

--- Insert Table 2 about here --- 
As it appears from the table, the data only bring statistical significant support to two of the hypotheses: namely $\mathrm{H}_{3}$ and $\mathrm{H}_{6}$. On a significance level of $<5 \%$, the results of the OLS regression support the hypothesis $\left(\mathrm{H}_{3}\right)$ that affiliates of MNCs with dispersed value chain configurations create more jobs in local firms than do affiliates in concentrated value chain configurations. The expected positive sign of the coefficient indicates more job-upgrading by the latter type of affiliates $\left(\mathrm{H}_{4}\right)$, but the relationship is statistically insignificant. Similarly, one of the two hypotheses associating local linkage effects to degree of inter-affiliate coordination found support (on a significance level of $<1 \%$; namely the contention that closely coordinated affiliates imply more job upgrading in local firms than do loosely coordinated affiliates $\left(\mathrm{H}_{6}\right)$. Although the sign of the coefficient is the expected negative one - indicating a moderated job creation effect as a result of close affiliate coordination $\left(\mathrm{H}_{5}\right)-$ the significance level is $>10 \%$. Our data analysis does not support the two first hypotheses $\left(\mathrm{H}_{1}\right.$ and $\left.\mathrm{H}_{2}\right)$ associating FDI motives and local job effects.

Hence, we find that firms with concentrated value chain configurations are significantly less inclined to create jobs at local linkage partners than are firms with dispersed value chain configurations. This is in accordance with our expectations: the more integrated the value chain, the more likely is internalization as disruptions at any site, be it in connection with upstream or downstream activities, may have serious repercussions for the functioning and reputation of the firm's entire value chain. Surprisingly, our sample finds no indication that the linkages fostered by MNCs with concentrated value chains are deeper in terms of resource commitment and upgrading efforts than those having more dispersed configurations.

Furthermore, we find that affiliates that are closely managed by the parent tend to have fewer linkages than those that are autonomous (however not significant), 
but are significantly more inclined to commit resources to upgrade local linkage partners. One interpretation could be that the factors explaining why parents keep affiliates under close scrutiny also explain control of local linkage partners. A corporate culture of centralization, monitoring, and control is likely to be transferred to the external links of the affiliates. Such a culture can be related to the industry of the MNC. An example is chemical companies which, due to high operational risks have little or no tolerance for compromises on safety and quality of inputs. Or, a centralization culture may follow a quality orientation. Hence, extremely qualityoriented MNCs will tend to extend their standards as well as monitoring and control practices to local linkage partners.

While we - as expected - find that the efficiency seeking investment motive is negatively correlated with linkages, this correlation is not significant. This lack of correlation is somewhat surprising given the strong indications in the literature that linkage practices and investment motives are closely interlinked. However, one may speculate if this literature reports phenomena of the past. It is beyond doubt that significant differences between the linkage practices of export-oriented and local market oriented affiliates have prevailed - mainly due to the widespread use of import substitution policies in developing countries. However, the wholesale phasing out of such policies may have prompted a convergence of local standards and standards applying to export markets - thereby dissolving the difference between linkage practices of efficiency and market seekers.

\section{Limitations of the study}

We would like to draw the reader's attention to the following three limitations of our empirical study: 
The first limitation concerns the sample size. With one exception $\left(\mathrm{H}_{2}\right)$ the results of the OLS regression analysis came out with the expected/hypothesized signs, but in three cases failed to reach the stipulated $10 \%$ minimum level of significance. This is probably due to the - after all - relatively limited number of observations.

Another possible weakness of the study pertains to its internal validity. The concepts of global integration and local responsiveness strategies are elusive, saying that it is extremely difficult to capture all aspects of these two strategies. Although the three manifestations of these two bi-polar strategies used in our models find considerable support in both theoretical and empirical studies other aspects may claim their relevance as well - e.g. perceptual measures of management orientation or measures based on content analyses of self-reported strategy statements.

Thirdly, the usual caveats remain about the external validity of small country firm samples - such as ours including MNCs from Denmark exclusively.

\section{Conclusions}

Although hard empirical evidence is still warranted, we have all reasons to believe that the megatrend of MNC strategies is that of a shift away from locally defined strategies of responsiveness towards strategies of global integration with concentrated value chain configurations and concomittant closely coordinated affiliate networks. In this study we have examined the implications of this trend in terms of local linkage effects in developing countries. We hypothesized that job creation in local firms diminishes as MNCs pursue strategies of global integration. However, we also hypothesized that this negative linkage effect may be tempered by more jobupgrading as a result of a global, corporate reliance on local operations. The two 
hypothesized interrelationships found some - although not irrefutable - empirical support in our study of FDIs in developing countries undertaken by Danish MNCs. Hence, more studies are warranted in order to establish whether or not these scope and depth job effects in developing countries hold true. If true, the gap between winners and loosers among developing countries may widen considerably. Developing countries capable of attracting FDIs creating local linkages to global value chains can expect sustainable export growth and permanent job gains. The MNCs' investments in local job upgrading are to a large extent irreversible, and the bargaining power of MNC investors vis-à-vis local governments weakens accordingly. All else being equal, MNCs’ pursuit of global integration strategies make them less 'footloose': they cannot switch activities from one developing country to another without incurring substantial exit costs.

\section{References}

Altenburg, T.(2000). Linkages and Spillovers between Transnational Corporations and Small and Medium-Sized Enterprises in Developing Countries - Opportunities and Policies. Pp. 3-61 in UNCTAD (Ed.), MNC-SME Linkages for Development. Issues - experiences - best practices. Proceedings of the Special Round on MNCs, SMEs and Development, UNCTAD X, 15 February 2000, Bangkok. Geneva: UN.

Bartlett, C.A., \& Ghoshal, S. (1989). Managing across borders. London: Century Business.

Belderbos R., Capannelli G. \& Fukao K. (2001). Backward Vertical Linkages of Foreign Manufacturing Affiliates: Evidence from Japanese Multinationals, World Development, 29 (1): 189-202. 
Best, M. (1999). Cluster dynamics in Theory and Practice: Singapore/Johor and Penang Electronics. Cambridge: Judge Institute of Management Studies.

Blomström, M. \& A. Kokko (1997). How Foreign Investment Affects Host Countries Development by helping to Improve Productivity Growth and Exports, Washington D.C.: World Bank Policy Research Working Paper.

Castellani, D. \& Zanfei, A. (2002). Multinational experience and the creation of linkages with local firms: Evidence from the electronics industry. Cambridge Journal of Economics, 26: 1-25.

Cypher, J. \& Dietz, J.L. (2004). The process of economic development. London: Routledge.

Dicken, P.(2003). Global Shift (4 $4^{\text {th }}$ ed.). London: Paul Chapman Publishing.

Doz, Y. (1980). Strategic management in multinational companies. Sloan Management Review, 21 (2): 27-46.

Dunning, J. (1992). The competitive advantage of nations and the activities of transnational corporations. Transnational corporations, 1(1): 135-168.

Dunning, J. (1993). Multinational Enterprises and the Global Economy. Essex: Addison-Wesley.

Dunning, J.(1997). Alliance capitalism and global business. London: Routledge.

Dunning, J. \& Narula, R. (1996). The Investment Development Path Revisited. Pp. 13-33 in J. Dunning \& R. Narula (Eds.), Foreign direct investment and governments: Catalysts for economic restructuring, London: Routledge. 
Esser, K., Wolfgang H., Messner, D. \& Meyer-Stamer, J. (1996). Systemic Competitiveness - New Governance Patterns for Industrial Development. London: Frank Cass.

Evans, P. (1998). Transnational corporations and Third World States: From the Old Internationalization to the New. Pp. 13-33 in Kozul-Wright \& Howtorn (Eds.), Transnational Corporations and the Global Economy. London: Macmillan Press.

Forsgren, M. (2002). Are multinational firms good or bad? Pp. 13-33 in V. Havila, M. Forsgren \& H. Håkanson (Eds.), Critical perspectives on internationalization. Oxford, UK: Elsevier Science Ltd.

Forsgren, M., Holm, U. \& Johanson, J. (2005). Managing the Embedded Multinational: A Business Network View. Cheltenham: Edward Elgar.

Frost, T.S, Birkinshaw, J.M. \& Ensign, P.C. (2000). Centers of excellence in multinational corporations. Strategic Management Journal, 23: 997-1018.

Gereffi, G., Humphrey, J. \& Sturgeon, T. (2005). The Governance of Global Value Chains. Review of International Political Economy, 11(1): 13-33.

Grant, R., Almeida, P., \& Song, J. (2000). Knowledge and the multinational enterprise. Pp. 102-129 in C. Millar (Ed.), International Business: Emerging Issues and Merging Markets. London: Macmillan.

Gupta, A.K. \& Govindarajan, V. (2000). Knowledge flows within multinational corporations. Strategic Management Journal, 21: 473-496. 
Görg H. \& Grenaway, D. (2002). Much ado about nothing? Do domestic firms really benefit from foreign direct investment? World Bank Research Observer, 19: 171197.

Hansen, M.W. \& Schaumburg-Müller, H. (Eds.) (2006). Transnational Corporations and Local Firms in Developing Countries - Linkages and Upgrading, Copenhagen: Copenhagen Business School Press.

Hansen, M. W., Pedersen, T. \& Petersen, B. (2006) Danish Investment in Developing Countries: A Global Value Chain Perspective, Copenhagen: Copenhagen Business School Press.

Hertner, P. \& Jones, G. (1986). Multinationals: Theory and History. London: Gower.

Holm, U. \& Pedersen, T. (Eds.) (2000). The Emergence and Impact of MNC Centers of Excellence. London: Macmillan.

Hoskisson, R.E., Eden, L., Lau, C.M. \& Wright, M. (2000). Strategy in Emerging Economies. Academy of Management Journal, 43: 249-267.

Humphrey, J. \& Schmitz, H. (2001). Governance in Global Value Chains. IDS Bulletin, Vol. 32: 19-29.

Kotabe, M. \& Murray, J.Y (2004). Global Sourcing Strategy and Sustainable Competitive Advantage. Industrial Marketing Management, 33(1): 7-14.

Koza, M.P. \& Lewin A.Y.(1998). The co-evolution of strategic alliances. Organization Science, 9 (3): 255-264.

Krugman, P. (1991). Geography and Trade. MA: MIT Press. 
Lall, S. (2002). FDI and Development: Research issues in the merging context. Pp. 168-191 in B. Bora (Ed.), Foreign Direct Investment: Research Issues. London: Routledge.

Lall, S. (1980). Vertical Inter-firm Linkages in LDCs: An Empirical Study. Oxford, UK: Oxford University Press.

Larimo, J, \& Tahir, R. (2003). Determinants of Ownership Strategies of Nordic Firms in Asian Countries - Empirical Evidence. Research Paper presented to the Seventh International Conference on Global Business and Economic Development, 8-11 January, Bangkok, 2003.

Lundvall, B.Å. (1998). Why Study National Systems and National Styles of Innovation? Technology Analysis \& Strategic Management, 10(4): 407-421.

Lundan, S. (2002). Network Knowledge in International Business. Cheltenham: Edward Elgar.

Porter, M.E. (1986). Competition in Global Industries: A Conceptual Framework. Pp. 1-33 in M.E. Porter (Ed.), Competition in Global Industries., Cambridge, MA, USA: Harvard Business School Press.

Porter, M.E. (1990). The Competitive Advantage of Nations. London: MacMillan Press.

Prahalad, C.K \& Doz, Y. (1987). The Multinational Mission: Balancing Local Demands and Global Vision. New York: Free Press.

Reuber, G.L. (1973). Private Foreign Investment in Development. Clarendon Press. 
Schmitz, H. \& Nadvi, K. (1994). Industrial Clusters in Less Developed Countries. Discussion Paper No 339, IDS.

Scott-Kennel, J. \& Enderwick, P. (2005). FDI and Inter-firm Linkages: Exploring the Black Box of the Investment Development Path. Transnational Corporations 14(1): 13-23.

Singer, H. (1950). The Distribution of Gains Between Investing and Borrowing Countries. American Economic Review (Papers and Proceedings), 40:473 - 85.

UNCTAD (2000a). The competitiveness challenge. TNCs and industrial restructuring in developing countries. Geneva: UNCTAD.

UNCTAD (2000b). Enhancing the competitiveness of SMEs through linkages. Background Paper prepared by the UNCTAD Secretariat, TD/B/COM.3/EM.11/2. Geneva: UNCTAD.

UNCTAD (2001). World Investment Report 2001. Promoting Linkages. N.Y.: UN, 2001.

Velde, D. (2002). Promoting MNC-SME linkages: The case for a global business linkage fund. Mimeo, Overseas Development Institute, 5 December 2002.

Wad, P (2006). The automotive supplier industry between localizing and globalizing forces in Malaysia, India and South Africa. Pp. 233-262 in M.W. Hansen, \& H. Schaumburg-Müller (Eds.), Transnational Corporations and Local Firms in Developing Countries - Linkages and Upgrading. Copenhagen: Copenhagen Business School Press. 
Wilkins, M. (1998). Multinational corporations: A historical account. Pp. 13-33 in Kozul-Wright \& Howtorn (Eds.), Transnational Corporations and the Global Economy. London: Macmillan Press.

Yip, G. (1992). Total Global Strategy: Managing for Worldwide Competitive Advantage. Prentice Hall.

Zaheer, S. \& Manrakhan, S. (2001). Concentration and Dispersion in Global Industries: Remote Electronic Access and the Location of Economic Activities. Journal of International Business Studies, 32: 667-686.

Zanfei, A. (2000). Transnational firms and the changing organisation of innovative activities. Cambridge Journal of Economics, 24: 515-542. 


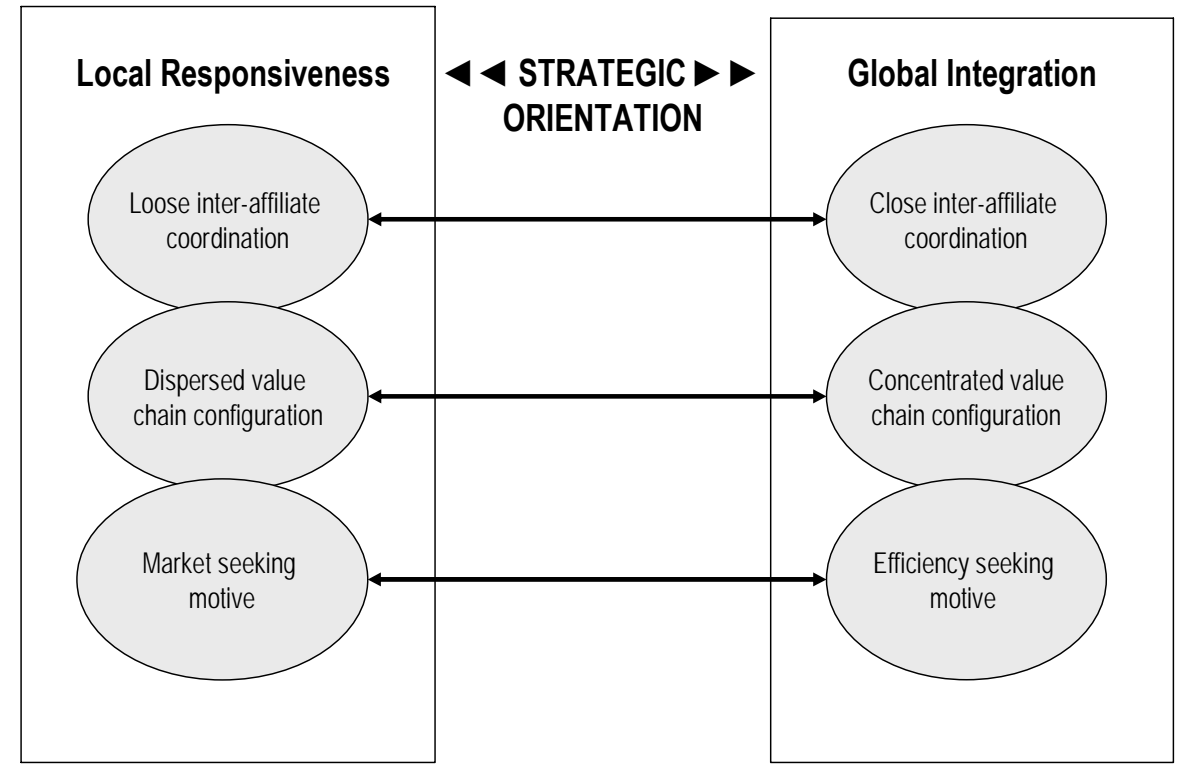

Figure 1: Bi-polar strategy manifestations on an integration-responsiveness scale

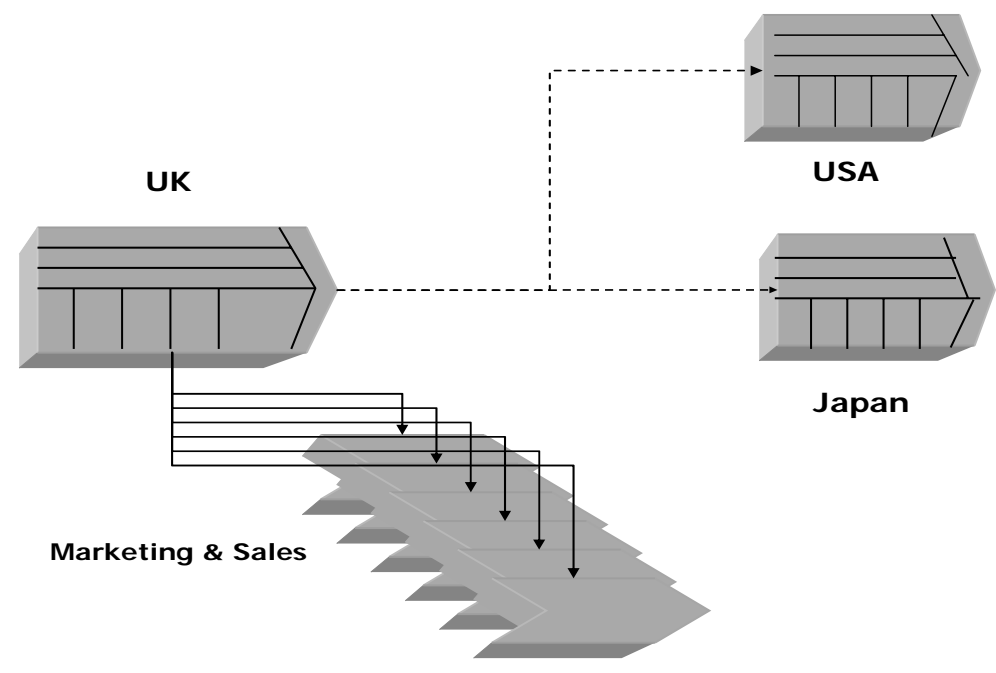

Figure 2: Example of a dispersed global value chain configuration. 


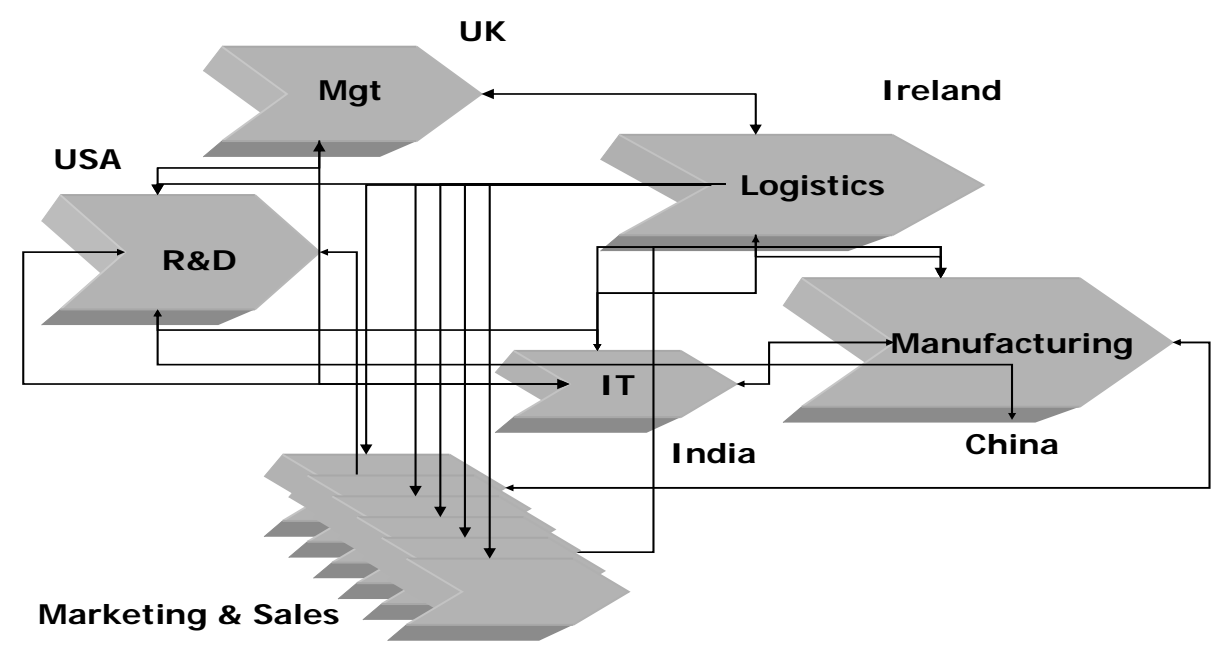

Figure 3: Example of a concentrated global value chain configuration.

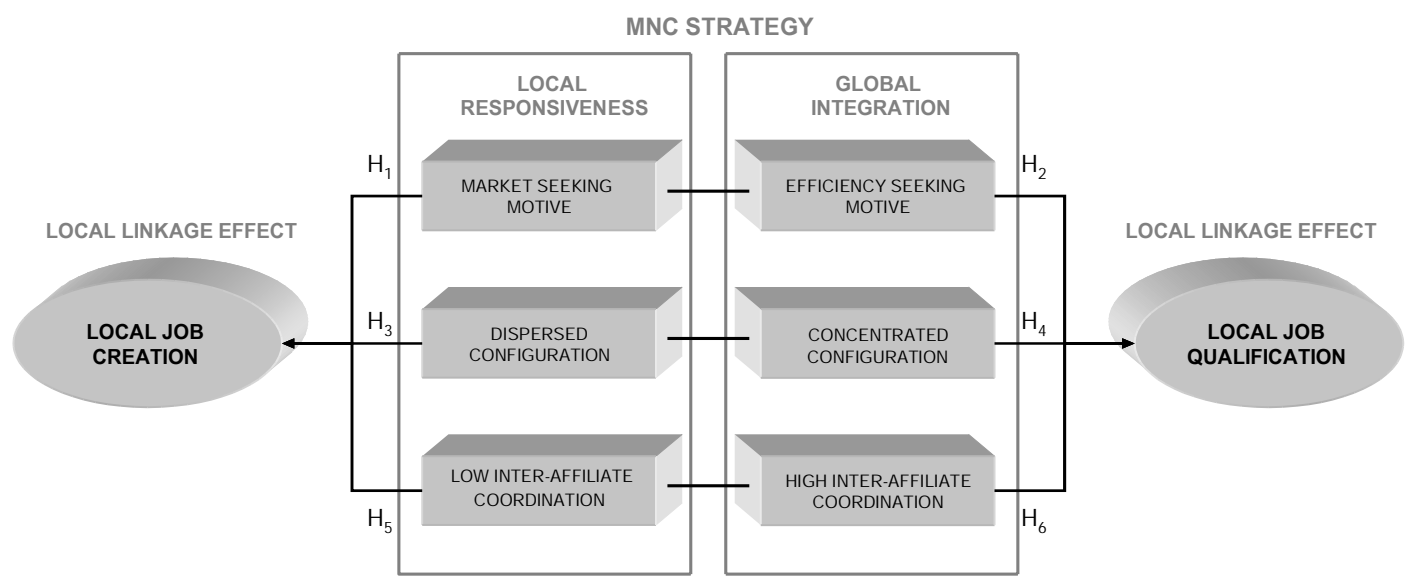

Figure 4: Conceptual model of the study 
Table 1: Correlation matrix for dependent and independent variables in the models

$\begin{array}{lllll}1 & 2 & 3 & 4 & 5\end{array}$

1. Efficiency seeking FDI motive

2. Concentrated configuration

$0.32^{\star \star \star} \quad 1.00$

3. Close inter-affiliate coordination

$0.26^{\star \star \star} \quad 0.16^{\star} \quad 1.00$

4. Local job creation

$\begin{array}{llll}-0.08 & -0.18^{*} & -0.14 & 1.00\end{array}$

5. Local job qualification

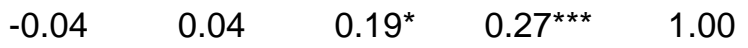

Mean

$\begin{array}{lllll}0 & 0.42 & 0 & 2.53 & 2.06\end{array}$

Std. error

$\begin{array}{lll}1.00 & 0.49 \quad 1.00\end{array}$

$4.63 \quad 2.27$

${ }^{*}, * *$ and ${ }^{* \star *}$ indicate a significance level of $1 \%, 5 \%$ and $10 \%$, respectively

Table 2: Results of OLS regression

\begin{tabular}{|c|c|c|}
\hline & Local job creation & Local job qualification \\
\hline Intercept & $1.58^{\star \star}$ & $1.93^{\star \star \star}$ \\
\hline Efficiency seeking FDI motive & -0.50 & -0.17 \\
\hline Concentrated configuration & $-2.24^{\star \star}$ & 0.36 \\
\hline Close inter-affiliate coordination & & \\
\hline F-value & -0.51 & $0.71^{\star \star \star}$ \\
\hline $\mathrm{N}$ & $2.33^{\star \star}$ & $2.49^{\star \star}$ \\
\hline
\end{tabular}

${ }^{*},{ }^{* *}$ and ${ }^{* \star *}$ indicate a significance level of $1 \%, 5 \%$ and $10 \%$, respectively. 


\section{SMG - Working Papers \\ www.cbs.dk/smg \\ 2003}

2003-1: Nicolai J. Foss, Kenneth Husted, Snejina Michailova, and Torben Pedersen: Governing Knowledge Processes: Theoretical Foundations and Research Opportunities.

2003-2: Yves Doz, Nicolai J. Foss, Stefanie Lenway, Marjorie Lyles, Silvia Massini, Thomas P. Murtha and Torben Pedersen: Future Frontiers in International Management Research: Innovation, Knowledge Creation, and Change in Multinational Companies.

2003-3: Snejina Michailova and Kate Hutchings: The Impact of In-Groups and OutGroups on Knowledge Sharing in Russia and China CKG Working Paper.

2003-4: Nicolai J. Foss and Torben Pedersen : The MNC as a Knowledge Structure: The Roles of Knowledge Sources and Organizational Instruments in MNC Knowledge Management CKG Working Paper.

2003-5: Kirsten Foss, Nicolai J. Foss and Xosé H. Vázquez-Vicente: “Tying the Manager's Hands": How Firms Can Make Credible Commitments That Make Opportunistic Managerial Intervention Less Likely CKG Working Paper.

2003-6: Marjorie Lyles, Torben Pedersen and Bent Petersen: Knowledge Gaps: The Case of Knowledge about Foreign Entry.

2003-7: Kirsten Foss and Nicolai J. Foss: The Limits to Designed Orders: Authority under "Distributed Knowledge" CKG Working Paper.

2003-8: Jens Gammelgaard and Torben Pedersen: Internal versus External Knowledge Sourcing of Subsidiaries - An Organizational Trade-Off.

2003-9: Kate Hutchings and Snejina Michailova: Facilitating Knowledge Sharing in Russian and Chinese Subsidiaries: The Importance of Groups and Personal Networks Accepted for publication in Journal of Knowledge Management.

2003-10: Volker Mahnke, Torben Pedersen and Markus Verzin: The Impact of Knowledge Management on MNC Subsidiary Performance: the Role of Absorptive Capacity CKG Working Paper.

2003-11: Tomas Hellström and Kenneth Husted: Mapping Knowledge and Intellectual Capital in Academic Environments: A Focus Group Study Accepted for publication in Journal of Intellectual Capital CKG Working Paper.

2003-12: Nicolai J Foss: Cognition and Motivation in the Theory of the Firm: Interaction or "Never the Twain Shall Meet"? Accepted for publication in Journal des Economistes et des Etudes Humaines CKG Working Paper.

2003-13: Dana Minbaeva and Snejina Michailova: Knowledge Transfer and Expatriation Practices in MNCs: The Role of Disseminative Capacity.

2003-14: Christian Vintergaard and Kenneth Husted: Enhancing Selective Capacity Through Venture Bases. 


\section{4}

2004-1: Nicolai J. Foss: Knowledge and Organization in the Theory of the Multinational Corporation: Some Foundational Issues

2004-2: Dana B. Minbaeva: HRM Practices and MNC Knowledge Transfer

2004-3: Bo Bernhard Nielsen and Snejina Michailova: Toward a Phase-Model of Global Knowledge Management Systems in Multinational Corporations

2004-4: Kirsten Foss \& Nicolai J Foss: The Next Step in the Evolution of the RBV: Integration with Transaction Cost Economics

2004-5: Teppo Felin \& Nicolai J. Foss: Methodological Individualism and the Organizational Capabilities Approach

2004-6: Jens Gammelgaard, Kenneth Husted, Snejina Michailova: Knowledge-sharing Behavior and Post-acquisition Integration Failure

2004-7: Jens Gammelgaard: Multinational Exploration of Acquired R\&D Activities

2004-8: Christoph Dörrenbächer \& Jens Gammelgaard: Subsidiary Upgrading? Strategic Inertia in the Development of German-owned Subsidiaries in Hungary

2004-9: Kirsten Foss \& Nicolai J. Foss: Resources and Transaction Costs: How the Economics of Property Rights Furthers the Resource-based View

2004-10: Jens Gammelgaard \& Thomas Ritter: The Knowledge Retrieval Matrix: Codification and Personification as Separate Strategies

2004-11: Nicolai J. Foss \& Peter G. Klein: Entrepreneurship and the Economic Theory of the Firm: Any Gains from Trade?

2004-12: Akshey Gupta \& Snejina Michailova: Knowledge Sharing in Knowledge-Intensive Firms: Opportunities and Limitations of Knowledge Codification

2004-13: Snejina Michailova \& Kate Hutchings: Knowledge Sharing and National Culture: A Comparison Between China and Russia

\section{5}

2005-1: Keld Laursen \& Ammon Salter: My Precious - The Role of Appropriability Strategies in Shaping Innovative Performance

2005-2: Nicolai J. Foss \& Peter G. Klein: The Theory of the Firm and Its Critics: A Stocktaking and Assessment

2005-3: Lars Bo Jeppesen \& Lars Frederiksen: Why Firm-Established User Communities Work for Innovation: The Personal Attributes of Innovative Users in the Case of Computer-Controlled Music

2005-4: Dana B. Minbaeva: Negative Impact of HRM Complementarity on Knowledge Transfer in MNCs

2005-5: Kirsten Foss, Nicolai J. Foss, Peter G. Klein \& Sandra K. Klein: Austrian Capital Theory and the Link Between Entrepreneurship and the Theory of the Firm 
2005-1: Nicolai J. Foss: The Knowledge Governance Approach

2005-2: Torben J. Andersen: Capital Structure, Environmental Dynamism, Innovation Strategy, and Strategic Risk Management

2005-3: Torben J. Andersen: A Strategic Risk Management Framework for Multinational Enterprise

2005-4: Peter Holdt Christensen: Facilitating Knowledge Sharing: A Conceptual Framework

2005-5 Kirsten Foss \& Nicolai J. Foss: Hands Off! How Organizational Design Can Make Delegation Credible

2005-6 Marjorie A. Lyles, Torben Pedersen \& Bent Petersen: Closing the Knowledge Gap in Foreign Markets - A Learning Perspective

2005-7 Christian Geisler Asmussen, Torben Pedersen \& Bent Petersen: How do we Capture "Global Specialization" when Measuring Firms' Degree of internationalization?

2005-8 Kirsten Foss \& Nicolai J. Foss: Simon on Problem-Solving: Implications for New Organizational Forms

2005-9 Birgitte Grøgaard, Carmine Gioia \& Gabriel R.G. Benito: An Empirical Investigation of the Role of Industry Factors in the Internationalization Patterns of Firms

2005-10 Torben J. Andersen: The Performance and Risk Management Implications of Multinationality: An Industry Perspective

2005-11 Nicolai J. Foss: The Scientific Progress in Strategic Management: The case of the Resource-based view

2005-12 Koen H. Heimeriks: Alliance Capability as a Mediator Between Experience and Alliance Performance: An Empirical Investigation Into the Alliance Capability Development Process

2005-13 Koen H. Heimeriks, Geert Duysters \& Wim Vanhaverbeke: Developing Alliance Capabilities: An Empirical Study

2005-14 JC Spender: Management, Rational or Creative? A Knowledge-Based Discussion

\section{6}

2006-1: Nicolai J. Foss \& Peter G. Klein: The Emergence of the Modern Theory of the Firm

2006-2: Teppo Felin \& Nicolai J. Foss: Individuals and Organizations: Thoughts on a Micro-Foundations Project for Strategic Management and Organizational Analysis

2006-3: Volker Mahnke, Torben Pedersen \& Markus Venzin: Does Knowledge Sharing Pay? An MNC Subsidiary Perspective on Knowledge Outflows

2006-4: Torben Pedersen: Determining Factors of Subsidiary Development 
2006-5 Ibuki Ishikawa: The Source of Competitive Advantage and Entrepreneurial Judgment in the RBV: Insights from the Austrian School Perspective

2006-6 Nicolai J. Foss \& Ibuki Ishikawa: Towards a Dynamic Resource-Based View: Insights from Austrian Capital and Entrepreneurship Theory

2006-7 Kirsten Foss \& Nicolai J. Foss: Entrepreneurship, Transaction Costs, and Resource Attributes

2006-8 Kirsten Foss, Nicolai J. Foss \& Peter G. Klein: Original and Derived Judgement: An Entrepreneurial Theory of Economic Organization

2006-9 Mia Reinholt: No More Polarization, Please! Towards a More Nuanced Perspective on Motivation in Organizations

2006-10 Angelika Lindstrand, Sara Melen \& Emilia Rovira: Turning social capital into business? A study of Swedish biotech firms' international expansion

2006-11 Christian Geisler Asmussen, Torben Pedersen \& Charles Dhanaraj: Evolution of Subsidiary Competences: Extending the Diamond Network Model

2006-12 John Holt, William R. Purcell, Sidney J. Gray \& Torben Pedersen: Decision Factors Influencing MNEs Regional Headquarters Location Selection Strategies

2006-13 Peter Maskell, Torben Pedersen, Bent Petersen \& Jens Dick-Nielsen: Learning Paths to Offshore Outsourcing - From Cost Reduction to Knowledge Seeking

2006-14 Christian Geisler Asmussen: Local, Regional or Global? Quantifying MNC Geographic Scope

2006-15 Christian Bjørnskov \& Nicolai J. Foss: Economic Freedom and Entrepreneurial Activity: Some Cross-Country Evidence

2006-16 Nicolai J. Foss \& Giampaolo Garzarelli: Institutions as Knowledge Capital: Ludwig M. Lachmann's Interpretative Institutionalism

2006-17 Koen H. Heimriks \& Jeffrey J. Reuer: How to Build Alliance Capabilities

2006-18 Nicolai J. Foss, Peter G. Klein, Yasemin Y. Kor \& Joseph T. Mahoney: Entrepreneurship, Subjectivism, and the Resource - Based View: Towards a New Synthesis

\section{7}

2007-1 Peter Abell, Teppo Felin \& Nicolai J. Foss: Building Micro-Foundations for the Routines, Capabilities, and Performance Links

2007-2 Michael W. Hansen, Torben Pedersen \& Bent Petersen: MNC Strategies and Linkage Effects in Developing Countries 